\title{
The Post-Racial and Post-Ethical Discourse OF DONALD J. TRUMP
}

\author{
ROBERT E. TERRILL
}

I n 2008, when Barack Obama became the 44th president of the United States, many heralded the arrival of a post-racial era. Some were cautious, others seemed to throw caution to the wind, but there was a widespread appreciation, or anticipation, that something new was happening with regard to the role of race in U.S. politics. Daniel Schorr, for example, on National Public Radio's (NPR's) All Things Considered, reported that "post-racial" was "the latest buzz word in the political lexicon"; Matt Bai, in the New York Times Magazine, wondered if "black politics might now be disappearing into American politics in the same way that the Irish and Italian machines long ago joined the political mainstream"; writing for Forbes, John McWhorter acknowledged that "nothing magically changed when Obama was declared president-elect" but went on to argue that "the election of Obama proved, as nothing else could have," that racism against African Americans in the United States is no longer "a serious problem."1

The 2016 campaign bore some similarities to the 2008 campaign. Hillary Clinton again faced a popular challenger for her party's nomination, for example, though this time she remained the frontrunner throughout. The Republican nominee was, again, a late-middle-aged white male who proudly declared that he does not follow the party line. And race, again, played an important role. But it would have been difficult to conclude that we stood at the threshold of a post-racial utopia. The campaign season was

ROBERT E. TERRILL is Professor of Rhetoric in the English Department at Indiana University, Bloomington.

(c) 2017 Michigan State University. All rights reserved. Rhetoric \& Public Affairs Vol. 20, №. 3, 2017, pp. 493-510. ISSN 1094-8392. 
marked by a constant stream of evidence to the contrary, both in popular culture and in campaign discourse itself. To provide a full account would require a much longer essay than this one, so I will focus only on the first few weeks of March 2016, which may be representative.

The month began in the wake of the Academy Awards, which were marred by a list of nominees that, for the second year in a row, included no people of color. The same weekend as the Oscars broadcast, a Catholic bishop denounced the actions of fans at a basketball game in Merrillville, Indiana, who waved pictures of Donald Trump and chanted "Build a wall!" to taunt their Latinx opponents. ${ }^{2}$ At about the same time, Nation of Islam leader Louis Farrakhan praised Trump for allegedly refusing donations from Jewish groups. And Trump faced some backlash after he did not immediately distance himself from a statement made by David Duke, former grand wizard of the Ku Klux Klan, to listeners to his radio program, that "voting against Donald Trump ... is really treason to your heritage."3 On March 6, during a televised Democratic debate, candidate Bernie Sanders said that white people "don't know what it's like to be living in a ghetto." On March 9, at a Trump rally in Fayetteville, North Carolina, an African American protestor was sucker-punched by a white male Trump supporter. ${ }^{5}$ The next day, at a news conference hosted by the Minneapolis chapter of the National Association for the Advancement of Colored People (NAACP), an African American couple voiced their exasperation at finding on their placemat at Joe's Crab Shack a photograph of a black man being hanged, accompanied by a comic-style speech balloon containing the words: "All I said was 'I don't like the gumbo." "The March 14 issue of the New Yorker featured cover art, drawn by Chris Ware, depicting an African American crossing guard holding up a stop sign between a police car occupied by two white officers and a small group of African American children. ${ }^{7}$ On March 20, George Will appeared on Fox News Sunday to warn that the Republican Party was in danger of becoming "the party of white people."

In the gap between what some feel is a colorblind ideal and the clear evidence that it has not come to pass, there have arisen several different types of postracial discourse. In this essay, I will describe three of these discourses. The first two have become relatively common, and share between them an obligation to address race. The third, however, while it may not be entirely new, has risen to recent prominence primarily in association with Donald Trump and lacks any sense of racial obligation. While the first two discourses acknowledge, to differ- 
ing extents and purposes, the significance of race in the history of citizenship in the United States, the third does not. I suggest, further, that acknowledging a sense of racial obligation is a fundamental component of ethical public speech in contemporary U.S. civic culture.

\section{Obligation}

The more familiar of the discourses of racial obligation is informed by what David Theo Goldberg has termed "racial neoliberalism," which, among other things, includes the tendency to equate the mere mention of race with an expression of racism. ${ }^{9}$ If colorblindness is an ideal, then anyone who invokes race threatens that ideal and is therefore a racist. Through this logic, racism is addressed most effectively when references to race are purged from civic culture. As Goldberg summarizes: "where no race, no racial harm. So no racism." The second discourse of racial obligation is a reaction to this aspirational racelessness and in some ways represents an inversion of it. Where in the first discourse we are obligated to talk about race in an effort to police it from the public sphere, in the second we are obligated to acknowledge race because we recognize its persistent public presence. This second discourse has become aligned with progressive politics, so that a credible presence in civic culture requires a recognition of both the existence and the significance of race.

In the first televised debate among Republican presidential candidates, hosted by Fox News on August 6, 2015, in Cleveland, Ohio, Ben Carson provided an almost textbook example of the discourse of racial neoliberalism. Near the end of the debate, Megyn Kelly, one of the three moderators, asked Dr. Carson what he would do to "heal" the racial divide. In response, Carson noted that he was once asked by an NPR reporter why he doesn't talk about race more often, and he said it was because he was a neurosurgeon. He clarified, to approving nods from his fellow candidates and a swell of applause from the audience:

You see, when I take someone to the operating room, I'm actually operating on the thing that makes them who they are. The skin doesn't make them who they are, the hair doesn't make them who they are, and it's time for us to move beyond that. Because, you know, our strength as a nation comes in our unity. We are the United States of America, not the divided states, and those who want to destroy us are trying to divide us and we shouldn't let them do it. ${ }^{11}$ 
This is a clear articulation of the colorblind ideal. The vignette depends on a privatization of race, as it is reduced to a merely superficial element of personal identity. ${ }^{12}$ Just as race allegedly is irrelevant to his work as a neurosurgeon, so too should race be irrelevant to our lives as citizens. Yet Carson's effort to minimize the significance of race is motivated not by its impotence but rather by its power; the threat of race is palpable enough that anyone who would allow it to penetrate the public sphere is attempting to destroy America. This, then, is a paraliptic discourse that draws attention to the very thing from which it purports to be distracting us. Ben Carson, an African American whose own racial identity undeniably was a significant factor in his popularity among conservatives, especially early in the campaign season-Rupert Murdoch opined on Twitter about how satisfying it would be to have a "real black" in the White House ${ }^{13}$ - tells us not to pay attention to race.

The complementary discourse of racial acknowledgment has not been codified as thoroughly as racial neoliberalism, and as a result it is difficult to capture in a single utterance. At its core is the expectation that progressive candidates for public office not only acknowledge race but also present an explicitly anti-racist stance. This expectation is evident, for example, in the criticism that Democratic candidate Bernie Sanders received early in the campaign for not referencing race often enough, leaving the impression, for some observers, that "these simply aren't issues Sanders is passionate about." ${ }^{\prime 4}$ Perhaps in response, Sanders added references to race and to the civil rights movement to his standard stump speech. ${ }^{15}$ But it was not until late February 2016, when archival video surfaced showing Sanders being arrested at a civil rights rally in 1963, that questions concerning his alignment with this discourse finally were put to rest.

In August 2015, when a group affiliated with Black Lives Matter were told that they could not attend a Hillary Clinton forum because the venue already was filled to capacity, the Clinton campaign contacted the group and set up a meeting. A spokesperson for the group asked Clinton, "now that you understand the consequences" of the crime bills that she supported in the past, which resulted in increased incarceration of African Americans, "what in your heart has changed that's going to change the direction of this country?"16 Clinton acknowledged the validity of the question, telling the group that "your analysis is totally fair. It's historically fair. It's psychologically fair. It's economically fair." And she gestured toward the realities of 
institutional racism in recognizing that "lip service" from white people who promise that they are "going to be nicer" is not enough. ${ }^{17}$

Perhaps the clearest example of this discourse during the campaign also was offered by Clinton. At a Democratic debate on January 17, 2016, in Charleston, South Carolina, she was invited to make a closing statement and said this:

I spent a lot of time last week being outraged by what's happening in Flint, Michigan, and I think that every single American should be outraged. We've had a city in the United States of America, where the population, which is poor, in many ways, and majority African American, has been drinking and bathing in lead contaminated water. And the governor of that state acted as though he didn't really care. ... I'll tell you what, if the kids in a rich suburb of Detroit had been drinking contaminated water and being bathed in it, there would have been action. ${ }^{18}$

In contrast to Carson, Clinton acknowledges the significance of race as well as the responsibility of those in power also to acknowledge its significance. Race here is treated as substantive, rather than superficial, and as a public issue, rather than a private attribute, as Clinton acknowledges that racial discrimination continues to impact the lives of her fellow citizens. And she does not single race out as a separate concern but instead brings it together with other systemic challenges to the formation of an equitable civic culture.

Both of these discourses respond to the ideal and the disappointment of post-racialism. Though racial neoliberalism purports to be discourse free of race, in practice it sees race as a persistent threat that continually menaces the body politic, and that therefore, as Ben Carson's statement illustrates, must be addressed in repeated rhetorical rituals of attempted purification. ${ }^{19}$ The progressive discourse of racial acknowledgment, in turn, establishes an expectation about addressing the significance of race that rises perhaps to the level of a left-of-center litmus test. In other words, both of these discourses, though in different ways, provoke an explicit recognition of race.

\section{OBVIATION}

Perhaps fittingly, given Trump's scattershot and often contradictory rhetorical style, he exceeds the expectations of post-racial discourse in two seem- 
ingly opposite ways. The first of these often was remarked upon throughout the campaign, as many observers have attributed Trump's political success, in part, to his willingness to say out loud what others have been willing only to imply. Where others have cloaked their racism and misogyny in coded language apt to be most clearly decoded by a specific and targeted audience, Trump speaks plainly, unconstrained by the bogeyman of "political correctness." In this view, Trump's core ideology differs little from that of the mainstream Republican Party, and his only innovation is in his mode of delivery: "Donald Trump is different only in degree. He has merely ditched the dog whistle and stripped away the code words." ${ }^{20}$

Such analyses were especially prevalent in response to Trump's delay in disavowing David Duke's endorsement. Jonathan S. Tobin, for Commentary, wrote that "there are such things as dog whistles in politics and the entire nation heard it loud and clear on Sunday when Donald Trump refused to disavow the endorsement of racist David Duke and the Ku Klux Klan or to condemn the group when asked about it on $\mathrm{CNN}^{\prime}$ 's 'State of the Union' Sunday morning program."21 Mark Danner, in the New York Review of Books, wrote that Trump "builds on and expresses loudly and clearly racist and nativist elements in Republican politics that have been central to the party's appeal since at least the mid-1960s but that its leaders have preferred to signal rather than enunciate. Trump leaves the dog whistle behind, puts his fingers to his lips, and screeches." ${ }^{22}$ Ben Fountain traces the history of conservative dog-whistle politics back at least to the "southern strategy" that helped to elect Richard Nixon and Ronald Reagan, and he provides as an exemplar Reagan's opening speech of his 1980 campaign for president, which was delivered in Philadelphia, Mississippi, where barely 16 years earlier civil rights activists Michael Schwerner, James Chaney, and Andrew Goodman had been executed by members of the KKK and buried in an earthen dam. ${ }^{23}$ In comparison, Trump's "racist rants play like fullfledged operas compared to the dog-whistle stuff, shredding the finely honed code that's worked so long and so well for the GOP establishment." ${ }^{24}$

The emergence of this form of rhetoric in mainstream American politics is disturbing for any number of reasons, not least of which being its appeal to so many of our fellow citizens. Even Mitt Romney, the Republican candidate for president in 2012, actively campaigned against his own party's frontrunner during the 2016 primaries, arguing that a Trump presidency would be a source of "trickle-down racism, trickle-down bigotry, trickle- 
down misogyny" and that "all these things are extraordinarily dangerous to the heart and character of America." 25

But for the remainder of this brief essay, I want to concentrate on the other way that Trump's racial rhetoric exceeds post-racial expectations: it is especially insidious not merely because it sheds pretenses and dog whistles but because it has shed any sense of racial burden. It fosters no obligation to acknowledge race, neither to negate nor to recognize its significance; it is not cleansed of references to race, of course, but it is almost entirely free of any explicit acknowledgment that race might, or should, impinge on its speakers or its hearers. It is, perhaps, a post-post-racial discourse-whereas rhetorics of post-racialism still express some obligation to address race, Trump very often does not. This rejection of a specifically racial burden establishes the context for, and thus enables, a wider rejection of the societal norms and expectations that provide the material for ethical speech.

I am referring to civic ethics, manifest in the manner in which citizens address fellow citizens. The ethical practice that Aristotle describes in the Nicomachean Ethics, as Eugene Garver reminds us, concerns "political virtues, while modern morality defines itself in opposition to the political. ${ }^{26}$ This is an ethics that emerges through public interaction within a civic context. ${ }^{27}$ Aristotle reminds us, further, that through ethical speech political leaders "make the citizens good by training them in habits of right action." ${ }^{28}$ In the contemporary United States, any ethical discourse would have to be one addressed to a diverse and heterogeneous citizenry and engaged in a project of encouraging and sustaining habits of right action that would constitute and perpetuate a more just, open, and equitable civic culture. It is for this reason that Danielle S. Allen argues that ethical speech does not entail treating everyone as though they were all members of an undifferentiated mass but rather as though we are all members of a diverse whole; she argues that the metaphor of "oneness" that characterizes the discourse of our civic sphere reinforces homogeneity and should be replaced with a metaphor of "wholeness" because that word has the capacity to acknowledge plurality and heterogeneity. ${ }^{29}$

Citizenship, as Allen points out, depends on an ethic of reciprocity and mutual sacrifice, such that all of us feel the burdens of being citizens together. If we act only "according to our own unrestrained interests," she warns, "we will corrode the trust that supports political bonds." ${ }^{30}$ Any mode of public address that speaks only in the language of self-interest, that 
sloughs off the burden of reciprocity, cannot contribute to an ethical civic culture. And race is the first burden that must be shouldered. As Allen puts it, "interracial distrust in the United States serves as a case study for thinking about the modes of citizenship that are generally needed to deal with congealed distrust." ${ }^{31}$ If we are to address one another as citizens, then we must learn to trust one another, and building trust across racial division may be the hard case-if we can do it there, then there is a chance we may achieve it elsewhere. A failure to recognize the role of race or to comprehend our need to acknowledge and respond to that role-again, even if that response consists only of the repeated acknowledgment racial recognition poses a threat to continued white dominance-attenuates severely our capacity to address one another as citizens. Racial recognition is a necessary but insufficient condition; neither Ben Carson's racial neoliberalism nor Hillary Clinton's discourse of racial acknowledgment is necessarily ethical, but at least these modes of address retain the potential to contribute to an ethical civic culture because they recognize a racial burden. The mode of public address that has found its most enthusiastic recent exponent in the person of Donald Trump, however, is utterly incapable of expressing, or participating in, a civic ethics.

\section{ADMONITION}

I attended a Donald Trump campaign rally in Indianapolis, Indiana, on April 20, 2016, the day after he had won the New York Republican primary with a commanding 59 percent of the vote. ${ }^{32}$ The rally was held in a cavernous building at the state fairgrounds, near downtown, and was attended by approximately 4,000 people. The audience was almost entirely white. ${ }^{33}$ After the requisite lineup of party operatives and local politicians had addressed the crowd, but before Trump took the stage, a disembodied voice came over the PA system assuring those gathered that Trump "supports the First Amendment just as much as he supports the Second Amendment" but still instructing audience members to chant "Trump! Trump! Trump!" whenever they encountered someone who, in their opinion, appeared to be disrupting the rally. This would signal the security detail, who then would remove the disruptor. ${ }^{34}$ The crowd was encouraged, in other words, to be self-policing, and during the course of the afternoon I would estimate that 30-40 people were escorted from the pavilion. The majority of 
these were African American, but the ejected also included a mixed-race group who were singing "This Little Light of Mine" and one white guy who was holding up a poster that read "Tom Brady Sucks." 35

Trump spoke without teleprompters, and seemingly without notes, delivering the basic stump speech that he had been repeating for months. The speech is loosely organized as a rather meandering list of assertions of toughness, appeals to vulnerability, and references to aggression, trickery, or danger associated with racially marked others. The structure is paratactic, so that there are few, if any, explicit connections between these references. Parataxis can open up new perspectives and invite audiences toward new opportunities for insight, for example, when a juxtaposition or paradox is sustained in a way that defers conclusions and thus promotes action or engagement. ${ }^{36}$ The lack of explicit connectives might invite audiences to resist collapsing wholeness into oneness, in Allen's terms, and thus invite them to embrace complexity and diversity. It might invite audiences to engage in a dialogue about race that recognizes that it is not a problem to be solved and safely filed away but an irresolvable and essential ingredient of our civic culture.

This is not its effect in Trump's hands. Trump does not invite us to move toward a more complex, diverse, or nuanced point of view but instead mires us in place, setting alongside one another a simplified repertoire of unsubstantiated observations that limit, rather than expand, perspective. The paratactic logic of Trump's speech is recursive, rather than progressive, and thus invites us to make the same connections, over and over, reinforcing existing ideological formations. The speech invites us to dig ourselves in, and then to defend our positions, so that our presumptions and prejudices are not questioned but calcified. We are invited not to open ourselves up to dialogue and possibility but to close ourselves down and to police the borders of our threatened imagined community.

Given the recursive, paratactic structure of Trump's speech, focusing on a single passage provides a representative anecdote of the whole. I have selected a particularly dense passage that begins approximately 30 minutes into the 55-minute address. The passage consists of three rather haphazardly organized sections: the first and third focus on China and Mexico, respectively, and bookend a second section about the use of torture.

As we all know by now, it is difficult to capture in writing the experience of listening to Trump speak, but I will summarize. He begins this passage by 
declaring that China has perpetrated "the greatest theft in the history of the world" and is among the countries that "have no respect for us." He then relates a story that appeared on the Drudge Report, and elsewhere, relating China's finance minister Lou Jiwei's critique of Trump's statements, and he characterizes Jiwei as "very angry . . . because I've exposed that they've been ripping us off for so many years." This is the type of thinking that is needed, Trump continues, "because our country is going to hell." Coal, however, is going to China, and "they burn it, and believe me," Trump says, "they don't clean it." In response to a disturbance in the audience, Trump explains that "if the crowd didn't say anything, you wouldn't hear [the protestors]; they have very weak voices." On the other hand, "it takes guts to run for president." Then, eliciting boos from the audience, Trump critiques the nuclear deal that the Obama administration made with Iran, in which "we give Iran 150 billion dollars [and] we get nothing," even though they roughed up, mentally and psychologically, our " 10 wonderful sailors." He finishes up this section by reminding the crowd, to cheers, that Vladimir Putin called him a genius.

A few moments later, Trump turns his attention to Mexico, reminding us that "last week, 16,500 border patrol agents endorsed Donald Trump," along with Joe Arpaio, the Maricopa County, Arizona, sheriff famous for his tough stance on immigration as well as for multiple allegations of racial profiling and for his continuing allegations that Obama's birth certificate is a forgery. People must come into the country legally, Trump continues, "or we don't have a country." He pauses to elicit cheers by asking, "Do we love the wall?" before offering an extended criticism of the former president of Mexico, Vicente Fox, for using the "F-bomb" in response to being asked if Mexico will pay for the construction of a border wall. The crowd then breaks into a "USA" chant, prompted by Trump's use of the phrase "America first." $\mathrm{He}$ conflates Americans of "Hispanic" descent with citizens of Mexico, saying that he has "great respect for Mexico" because the "thousands of Hispanics who work for me" are "phenomenal people." He reminds us that he did very well in the Republican primary debates, standing at "center stage" every time. And he concludes this passage by arguing that we'll be able to build the wall because, "in China, they built a wall 13,000 miles long." 37

While there is little point in attempting to identify logical connections between these various assertions, they do display a wandering oscillation between images of toughness and vulnerability and implicit images of racial 
difference associated with theft, anger, deception, impropriety, and dirt. Though this is a discourse characterized by the paradox of white masculine toughness and vulnerability, and populated by unsavory and uncivilized nonwhite others, race is never explicitly acknowledged. This is an example of dog-whistle rhetoric, of course, but more significantly, this refusal to acknowledge race allows the formation of a narrow, fearful mode of address in which there is no space for acknowledging the burdens of reciprocity. It is, indeed, a discourse that depends upon, and reinforces, a sense that we already are suffering under excessive and unwarranted burdens. ${ }^{38}$ Invited to perceive ourselves as confronted by a horde of seemingly material problems, we have no time to consider so spectral a thing as race. This insulary and self-interested discourse is possible only in the context of a thorough failure to acknowledge any form of shared or collective obligation.

Sandwiched between these two reflections on the dangers of China and Mexico-and implicitly, of the dangers of Chinese and Mexicans-Trump discusses torture, an act that implicates both toughness and vulnerability and, in the contemporary political climate, race. The quality of this section is best appreciated if quoted in its entirety:

You know, for years, for years and years, I'd read about medieval times. I love history. And in medieval times, they chopped off heads. But when do they do this? Now, we're living in medieval times. We're weak, we're ineffective. During one of the debates, they asked Lying Ted [Cruz] about, about waterboarding. And he didn't want to answer because it was a very, you know, it was a question, what do you think about waterboarding. And he didn't want to get involved because he was afraid that it wasn't politically correct. And he gave a nothing answer, a weak, pathetic answer like we always give. They asked me, what do you think about waterboarding, Mr. Trump. I said I love it. I love it. Think it's great. And I said the only thing is, we should make it much tougher than waterboarding. And if you don't think it works, folks, you're wrong. But, you know, there are laws. We have laws that we have to abide by. So I said we're going to have to strengthen the laws and toughen up the laws and we're going to have to make ourselves tougher. Because they can chop off heads, they can drown people in steel cages, right? - they can put people in steel cages, by 25 and 50 people, and drop them in the water, and pull them up an hour later-and we can't waterboard. How stupid are we. How stupid are we. 
This is a gleefully unburdened and, thus, perversely unethical discourse. It is liberated not only from the restraints of grammar, logic, and coherence but also from any sense of obligation to anyone but the speaker and those who would identify with him. This is a discourse motivated entirely by self-interest, focused exclusively on ends, and dismissive of societal norms. It invites no kind of deliberation but instead urges us to reject any limitations on thought and action, whether represented by laws, political correctness, or common decency, and frames any willingness to abide by such constraints as a form of weakness. Making ourselves tougher translates into throwing off the shackles of reciprocity, so that we may engage in an unrestrained display of raw power. Trump establishes waterboarding, beheading, and cage drowning as mutually barbaric practices and then calls our refusal to participate in such practices "stupid." When he says he loves waterboarding, members of the audience cheer; when he reminds them that "we have laws that we have to abide by," they jeer.

\section{CONCLUSION}

Shelby Steele, a senior fellow at Stanford's Hoover Institute, explains that a discourse of post-racialism offers white audiences a bargain: "It seduces whites with a vision of their racial innocence precisely to coerce them into acting out of a racial motivation. ${ }^{39}$ It is a discourse, in other words, that expunges white guilt so completely and so thoroughly that it gives permission for white people to act in their own self-interest. Steele has argued that Barack Obama was an especially potent purveyor of this post-racial bargain, and that this was a significant source of his political success in 2008: Obama generally avoided the topic of race, thereby relieving white liberals of their sense of responsibility, and they, in return, offered him their support. ${ }^{40}$ In 2016, Ben Carson offered conservatives a similar version of this bargain.

Donald Trump offers something different. In his hands, the bargain twists into a license for unfettered racial manipulation. Obama's dark body grounds the bargain in a racial presence and thus tethers it to the fundamental exclusions that have marked, and continue to mark, U.S. citizenship. Something similar happens when Ben Carson offers the conservative version of this bargain, even though the racial grounding may be accepted by his supporters as ironic. Clinton cannot offer her audiences her own racially 
marked body, of course, but she can embrace a discourse of racial recognition that is intended to implicate her in the political realities of a non-postracial civic culture. ${ }^{41}$ Trump offers no such ground and in fact pulls it from under our feet. The a-racial discourse upon which he built his candidacy offers no invitation toward building racial trust and no recognition of shared civic burdens, and it instead presents a free-floating assortment of vague assertions that are thrillingly untethered from the norms and obligations that might enable civic virtue. He invites us to reject all such burdens, and as a consequence he rejects Aristotle's burden to lead his followers toward habits of right action. Trump fails spectacularly Allen's first test for ethical speech-indeed, rejects any notion that he, or his audience, should subject themselves to any such test-and cannot approach any subsequent standard.

At one point in his speech at Indianapolis, Trump assured his audience that "we have the safest rallies, and probably the safest places to be, anywhere in the country." This ignores, of course, the anxiety and precarity that Trump's words elicit for many citizens, including women, people who identify as LGBTQ, people who are disabled, and people of color. But nonetheless, this phrase captured in a nutshell much of the appeal of Trump's campaign. He crafted both a material and a discursive space where his overwhelmingly white audiences felt safe because it was a space within which they are insulated from the burdens of reciprocity and where citizenship is reduced to self-interest. The unburdening takes its initial form in its refusal to recognize the significance of race, but then, as is evident in the passage concerning torture, is generalized into an all-encompassing discourse of self-interested toughness as a corrective to our current vulnerability before threatening racial others. This may not be an entirely new discourse in our politics, but it is different from the discourses of racial neoliberalism and racial acknowledgment that have dominated recent U.S. political campaigns.

Michael J. Hyde has reminded us that "the ethical practice of rhetoric entails the construction of a speaker's ethos as well as the construction of a 'dwelling place' (ethos) for collaborative and moral deliberation." 42 In the United States, constituting a stable place for ethical discourse, one with the potential for producing moral citizens and sustaining collaborative deliberation, requires an explicit acknowledgment of the continuing significance of race. Trump offers us, instead, a chaotic refuge menaced on all sides by 
suspicion, fear, distrust, and self-aggrandizing triumphalism. Trump invites us to dwell in a space that closes down the possibility for ethical speech and moral action, all the more insidiously because it cloaks itself in the false purity of racial innocence. It is difficult to imagine a discourse less adequate for the cultivation of civic virtue or more corrosive to democratic ideals.

\section{NOTES}

1. Daniel Schorr, “A New, 'Post-Racial' Political Era in America," National Public Radio, January 28, 2008, http://www.npr.org/templates/story/story.php?storyId=18489466; Matt Bai, "Is Obama the End of Black Politics?" New York Times Magazine, August 6, 2008, http://www.nytimes.com/2008/08/10/magazine/10politics-t.html; and John McWhorter, "Racism in America Is Over," Forbes, December 30, 2008, http://www.forbes.com/ 2008/12/30/end-of-racism-oped-cx_jm_1230mcwhorter.html.

2. "Catholic Bishop Admonishes Students for Pro-Trump Chants," CBSNews.com, February 29, 2016, http://www.cbsnews.com/news/indiana-catholic-schoolstudents-trump-chants-basketball-game.

3. Nolan D. McCaskill, "Louis Farrakhan Praises Donald Trump," Politico.com, March 1, 2016, http://www.politico.com/blogs/2016-gop-primary-live-updates-and-results/2016/03/ louis-farrakhan-donald-trump-220021; and Eliza Collins, "David Duke: Voting against Trump Is ‘Treason to Your Heritage,”' Politico.com, February 25, 2016, http://www.politico.com/story/2016/02/david-duke-trump-219777.

4. Amanda Terkel, "Bernie Sanders: White People Don't Know What It's Like to Live in the 'Ghetto,'” Huffington Post, March 6, 2016, http://www.huffingtonpost.com/ entry/bernie-sanders-ghetto_us_56dce712e4b03a405679062b.

5. Justin William Moyer, Jenny Starts, and Sarah Larimer, "Trump Supporter Charged After Sucker-Punching Protestor at North Carolina Rally," WashingtonPost.com, March 11, 2016, https://www.washingtonpost.com/news/morning-mix/wp/2016/03/10/ trump-protester-sucker-punched-at-north-carolina-rally-videos-show.

6. Avianne Tan, “Joe's Crab Shack Under Fire for Using Photo of Black Man's Hanging as Table Décor," ABCNews.go.com, March 11, 2016, http://abcnews.go.com/US/joes-crabshack-fire-photo-black-mans-hanging/story?id $=37580530$.

7. Chris Ware, “Cover Story: 'Stop,' by Chris Ware," New Yorker, March 7, 2016, http://www.newyorker.com/culture/culture-desk/cover-story-2016-03-14.

8. David Edwards, “George Will Shreds Trump's New Republican Party: 'He’s Appealing Entirely to White People," RawStory.com, March 20, 2016, http://www.rawstory. 
com/2016/03/george-will-shreds-trumps-new-republican-party-hes-appealing-entirelyto-white-people.

9. David Theo Goldberg, The Threat of Race: Reflections on Racial Neoliberalism (Oxford, UK: Wiley-Blackwell, 2009), 345, 360. See also Darrel Enck-Wanzer, "Barack Obama, the Tea Party, and the Threat of Race," Communication, Culture and Critique 4 (March 2011): 28.

10. Goldberg, The Threat of Race, 334 .

11. "First Republican Primary Debate-Main Stage-August 6, 2015," https://youtu.be/ $2 r U 4 W 3 y f d 58 ? t=6217$.

12. Goldberg, The Threat of Race, 337.

13. David A. Graham, "A Short History of Whether Obama Is Black Enough, Featuring Rupert Murdoch," TheAtlantic.com, October 8, 2015, http://www.theatlantic.com/ politics/archive/2015/10/a-short-history-of-whether-obama-is-black-enough-featuringrupert-murdoch/409642. See also Andrew Prokop, "Ben Carson Has Surged into 2nd Place Behind Trump. Here's Why," Vox.com, September 16, 2015, http://www.vox.com/2015/9/6/9262795/ben-carson-polls.

14. Dara Lind, “Why Bernie Sanders Doesn't Talk about Race," Vox.com, July 18, 2015, http://www.vox.com/2015/5/27/8671135/bernie-sanders-race.

15. Dan Merica, "Bernie Sanders Adds Race, Civil Rights to His Stump Speech," CNN.com, July 3, 2015, http://www.cnn.com/2015/07/02/politics/bernie-sanders-civil-rights2016-election.

16. Dan Merica, "Black Lives Matter Videos, Clinton Campaign Reveal Details of Meeting," CNN.com, August 18, 2015, http://www.cnn.com/2015/08/18/politics/hillaryclinton-black-lives-matter-meeting. A transcript of the exchange is available here: http://politic365.com/2015/08/18/full-transcript-hillary-clinton-convo-withblacklivesmatter. A video recording is available here: https://www.youtube.com/ watch? $v=1 e C r a U v I q-s$.

17. Regrettably, Clinton went on to offer advice to the group, saying that they should "find some common ground on agendas that can make a difference right here and now in people's lives" so that then "you can be for something." The spokesperson for the group responded: “The piece that's most important, and I stand here in your space, and I say this as respectfully as I can, but you don't tell black people what we need to know. And we won't tell you all what you need to do." See also this interview with Daunasia Yancey, a founder of Black Lives Matter, in which she calls Clinton's record on racial justice "abysmal": http://www.npr.org/2015/08/20/433257673/black-lives-matteractivist-hillary-clintons-racial-justice-record-is-abysmal. Clinton was confronted again by Black Lives Matter protestors at a private fundraiser in Charleston, South Carolina, 
in February 2016. This time the activists bought $\$ 500$ tickets to attend the event and again challenged her on statements she made in 1994 in support of the crime bill. The activists were escorted out of the event, but afterward, Clinton issued a statement in which she acknowledged that “I shouldn't have used those words, and I wouldn't use them today." Eugene Scott, "Black Lives Matter Protestors Confront Clinton at Fundraiser," CNN.com, February 25, 2016, http://www.cnn.com/2016/02/25/ politics/hillary-clinton-black-lives-matter-whichhillary.

18. "NBC News-YouTube Democratic Debate (Full)," https://youtu.be/ ti2Nokoq1J4? $t=6644$.

19. Though Goldberg describes this discourse as "racism without race," the illustrative examples he provides actually show an explicit policing of race similar to Carson's: Condoleezza Rice allegedly recommending that people in the United States should forget about slavery and George W. Bush acknowledging to the NAACP that though laws have been changed, racism still lingers in the hearts of some Americans. Goldberg, Threat of Race, 23.

20. Dick Polman, "The Party of Trump: Racism without the Dog-Whistle," NewsWorks.com, March 2, 2016, http://www.newsworks.org/index.php/local/ national-interest/91503-the-party-of-trump-racism-without-the-dog-whistle.

21. Jonathan S. Tobin, “Trump's Very Loud Dog Whistle," Commentary.com, February 29, 2016, https://www.commentarymagazine.com/politics-ideas/campaigns-elections/ trumps-loud-dog-whistle.

22. Mark Danner, "The Magic of Donald Trump," New York Review of Books, May 29, 2016, http://www.nybooks.com/articles/2016/05/26/the-magic-of-donald-trump.

23. The investigation into the deaths of these civil rights workers has only recently been closed. Campbell Robertson, "Mississippi Ends Inquiry into 1964 Killings of 3 Civil Rights Workers," New York Times, June 20, 2016, http://www.nytimes.com/2016/ 06/21/us/mississippi-ends-inquiry-into-1964-killing-of-3-civil-rights-workers.html.

24. Ben Fountain, "American Crossroads: Reagan, Trump, and the Devil Down South," TheGuardian.com, March 5, 2016, http://www.theguardian.com/us-news/ 2016/mar/05/trump-reagan-nixon-republican-party-racism.

25. Theodore Schleifer, "Mitt Romney Says Donald Trump Will Change America with 'Trickle-Down Racism," CNN.com, June 11, 2016, http://www.cnn.com/2016/06/10/ politics/mitt-romney-donald-trump-racism/index.html. Of course, Romney himself engaged in one of the most famous examples of racial dog-whistle rhetoric when, during his 2012 campaign for president, he referred to a " 47 percent" of Americans who are dependent on government programs and lack "personal responsibility and care for their lives." Romney also sought Trump's endorsement, in 2012, in the wake of 
Trump's alignment with "birthers" who did not believe that Barack Obama was born in the United States. And then, in a particularly peculiar twist, after Trump was elected, Romney emerged among those who seemed to be under consideration for secretary of state in the Trump administration.

26. Eugene Garver, Confronting Aristotle's Ethics: Ancient and Modern Morality (Chicago, IL: University of Chicago Press, 2008), 126-27. This is to be differentiated, for example, from the "virtue ethics" described by John Duffy, which concerns a more personal and less explicitly or specifically public sense of ethics. Duffy, "The Good Writer: Virtue Ethics and the Teaching of Writing," College English 793 (2017): 229-50. The syndicated columnist Judith Martin, who writes as Miss Manners, offers a complementary distinction: "There ... is an unfortunate tendency to confuse manners, which pertain to the outer person, with morals, which belong in such interior realms as the conscience and the soul." Judith Martin, Common Courtesy: In Which Miss Manners Solves the Problem That Baffled Mr. Jefferson (New York: Atheneum, 1985), 9. Civic ethics inhabit the realm of manners, rather than morals.

27. Craig R. Smith, "Ethos Dwells Pervasively," in The Ethos of Rhetoric, ed. Michael J. Hyde (Columbia: University of South Carolina Press, 2004), 6.

28. Aristotle, The Nicomachean Ethics, trans. H. Rackham (Cambridge, MA: Harvard University Press, 1926), II.i.5.

29. Danielle S. Allen, Talking to Strangers: Anxieties of Citizenship Since Brown v. Board of Education (Chicago, IL: University of Chicago Press, 2004), 16, 87.

30. Allen, Talking to Strangers, 137.

31. Allen, Talking to Strangers, xxi.

32. A video recording of the speech is available here: "Full Speech: Donald Trump Holds Huge Rally in Indianapolis, IN (4-20-2016),” https://www.youtube.com/ watch? $v=g Q c O K T k O l 4 U$.

33. According to 2000 census data, Indianapolis is 25 percent black.

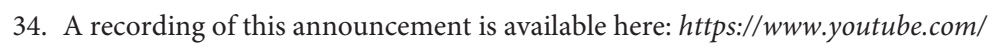
watch? $v=c H F 1 x O H 19 D c$. It appears to have been read from a script before every Trump rally.

35. Tom Brady is the quarterback for the New England Patriots, a long-time rival of the Indianapolis Colts, and had publicly endorsed Trump.

36. Robert E. Terrill, Double-Consciousness and the Rhetoric of Barack Obama: The Price and Promise of Citizenship (Columbia: University of South Carolina Press, 2015), 23-24.

37. Trump's tone and facial expression suggest that this is intended as a form of racial $a$ fortiori argument: if a nonwhite nation like China can build a wall, then surely we can. 
38. Trump's discourse perhaps speaks most directly to white males who feel that they are disadvantaged by recent economic and demographic changes. See Tami Luhby, "The Men America Has Left Behind," Money.CNN.com, May 4, 2016, http://money.cnn. com/2016/05/04/news/economy/america-left-behind-white-men/index.html; and John Blake, "It's Time to Talk about 'Black Privilege,"” CNN.com, March 31, 2016, http://www.cnn.com/2016/03/30/us/black-privilege/index.html.

39. Shelby Steele, "Obama's Post-Racial Promise," Los Angeles Times, LATimes.com, November 5, 2008, http://www.latimes.com/opinion/opinion-la/la-oe-steele52008nov05-story.html.

40. Shelby Steele, A Bound Man: Why We Are Excited about Obama and Why He Can't Win (New York: Free Press, 2008), 98.

41. Clinton is aided here, as well, by her female body as well as by the fact that Toni Morrison once pronounced her husband America's "first black president." Toni Morrison, “The Talk of the Town: Comment," New Yorker, October 5, 1998, http://www.newyorker.com/archive/1998/10/05/1998_10_05_031_TNY_LIBRY_ 000016504.

42. Michael J. Hyde, "Introduction: Rhetorically, We Dwell," in The Ethos of Rhetoric, ed. Michael J. Hyde (Columbia: University of South Carolina Press, 2004), xviii. 
Copyright of Rhetoric \& Public Affairs is the property of Michigan State University Press and its content may not be copied or emailed to multiple sites or posted to a listserv without the copyright holder's express written permission. However, users may print, download, or email articles for individual use. 